\title{
EKSPLORASI RUANG OLAHRAGA DAN SENI
}

\author{
Sitta Faradilla ${ }^{1)}$, Suryono Herlambang ${ }^{2)}$ \\ ${ }^{1)}$ Program Studi S1 Arsitektur, Fakultas Teknik, Universitas Tarumanagara,sitta.paradilla@gmail.com \\ ${ }^{2)}$ Program Studi S1 PWK, Fakultas Teknik, Universitas Tarumanagara, s.herlambang@gmail.com
}

Masuk: 14-07-2020, revisi: 01-08-2020, diterima untuk diterbitkan: 23-09-2020

\begin{abstract}
Abstrak
Kegiatan olahraga dan seni merupakan kegiatan yang dapat menghilangkan rasa kejenuhan rutinitas dan aktivitas sehari - hari yang sangat padat, sehingga dapat mengurangi tingkat kejenuhan yang dialami oleh masyarakat dari mulai anak - anak hingga orang tua. Pusat komunitas olahraga dan seni adalah sebuah wadah interaksi bagi masyarakat dari mulai anak - anak hingga orang tua. Proyek ini didesain sebagai pusat kegiatan bersama masyarakat Kelurahan Wijaya Kusuma dengan misi menjadi fasilitas edu wisata yang terbuka bagi masyarakat untuk berinteraksi, bertukar pikiran, menghilangkan kejenuhan dengan melakukan kegiatan olahraga dan seni. Cross - proggraming dengan menggunakan ruang spasial yang tidak sesuai dengan fungsi asalnya seperti aktivitas yang tumpang tindih merupakan salah satu metode desain yang digunakan dalam proyek ini. Metode tipe perilaku digunakan untuk menganalisa program dalam peranangan. Program edukasi dalam proyek ini terdiri dari ruang kelas kegiatan seni dan juga olahraga. Sedangkan program rekreasi dalam proyek ini terdiri dari kegiatan olahraga dan juga seni yang berada di luar bangunan seperti taman, jogging track, friendly playground, sitting group dan area kolam renang.
\end{abstract}

Kata kunci: anak-anak hingga orang tua; fasilitas edu wisata; kegiatan olahraga; seni

\begin{abstract}
Sports and art activities are activities that can eliminate feel bored of routinity and daily activities that are very dense, so as to reduce the level of boredom experienced by the community from children up to parents. The sports and arts community center is a forum interaction for everybody. This project was designed as a center of activities with the community of Wijaya Kusuma Village with a mission to become an educational facility that is open for the community to interact, exchange ideas, eliminate boredom by doing sports and arts activities. Cross - programming using spatial spaces that not fit the original function such as overlapping activities is one of the design methods used in this project. Behavioral type methods are used to analyze programs in roles. The education program in this project consists of classrooms for arts and sports activities. While the recreation program in this project consists of sports activities and also art that is outside the building such as parks, jogging tracks, friendly playgrounds, sitting groups and swimming pool areas.
\end{abstract}

Keywords: art; children to parent; educational facilities; sports activities

\section{PENDAHULUAN}

\section{Latar Belakang}

Perkembangan kota Jakarta berlansung dengan cepat. Dengan banyaknya pembangunan semakin mengukuhkan Jakarta sebagai pusat dari semua kegiatan pemerintahan, bisnis, sosial, serta hiburan di Indonesia. Jakarta menjadi tujuan utama masyarakat setempat ataupun luar daerah yang berbondong - bondong untuk mencari kehidupan yang lebih baik. Namun perkembangan kota Jakarta yang pesat dengan jumlah penduduk yang kian bertambah hingga 4\% atau sekitar 222.738 jiwa pertahunnya (Dinas Kependudukan dan Catatan Sipil, 2005) yang 
tidak dibarengi oleh ketersediaan lahan sebagai tempat tinggal, sehingga harga tanah di Jakarta semakin mahal. Di sisi lain kehidupan di perkotaan tidak lepas dari kejenuhan akan rutinitas dan aktivitas sehari - hari yang sangat padat, hal ini menyebabkan meningkatnya rasio kemungkinan stres di kota - kota besar seperti Jakarta cukup tinggi. Hal ini terjadi tidak hanya pada orang dewasa tetapi semua mengalami hal tersebut dari mulai anak - anak hingga orang dewasa, yang mana pada usia anak - anak hingga remaja mereka seharusnya dapat mengembangkan dirinya akan tetapi karena hal tersebut mereka jadi kurang dapat mengekspresikan dirinya. Ditengah - tengah tuntutan serta rutinitas sehari - hari banyak orang yang mencari hiburan ataupun tempat rekreasi untuk sekedar melepas kepenatan dari aktivitas sehari - hari.

Pada dasarnya manusia merupakan makhluk yang memiliki kemampuan berinteraksi dan bertindak sebagai makhluk individu maupun makhluk sosial. Sebagai individu manusia dapat melakukan komunikasi bedasarkan tiga poin utama yaitu, persepsi terhadap pribadi, kesadaran pribadi, dan pengungkapan diri. Hal tersebut menjadi wajar karena adanya unsur karakteristik dan jati diri yang berbeda disetiap individu. Namun dalam perjalanannya mausia tidak dapat terus - menerus berperan sebagai individu, manusia pada dasarnya sebagai makhluk sosial yang membutuhkan ruang tersendiri sebagai bagian dari proses pengembangan. Peran ruang interaksi dan pengembangan diri bagi masyarakat Wijaya Kusuma sangat penting, selain menyangkut tata runag fisik lingkungan, ruang publik juga mengemban fungsi dan makna sosial yang sangat tinggi. Namun, pertumbuhan kota yang cepat menyebabkan tuntutan kebutuhan lahan perkotaan makin meningkat. Privatisasi lahan baik secara individual maupun badan hukum atau lembaga lain telah menyebabkan eksistensi ruang publik semakin terpinggirkan. Bahkan di permukiman padat penghuni, masyarakat sudah tidak lagi meiliki ruang publik yang memadai untuk mewadahi aktivitas mereka. Di sisi lain, miskinnya ruang publik yang dapat menampung berbagai aktivitas bersama dikhawatirkan terjadi berbagai masalah sosial kemasyarakatan sebagai akibat dari kurangnya kebersamaan dan sosialisasi antar warga. Masyarakat yang tidak lagi memiliki ruang bersama untuk saling berinteraksi, komunikasi antar warga, anak - anak tidak lagi memiliki tempat bermain di ruang luar, sehingga budaya kebersamaan dan toleransi semakin terkikis.

\section{Rumusan Permasalahan}

a. Bagaimana peranan Third Place dalam menunjang kehidupan masyarakat di kelurahan Wijaya Kusuma?

b. Bagaimana program untuk memenuhi kebutuhan masyarakat kelurahan Wijaya Kusuma yang sesuai dengan tipe, perilaku, dan aktivitas?

c. Bagaimana cara meningkatkan produktivitas dan keseimbangan sosial masyarakat kelurahan Wijaya Kusuma?

d. Bagaimana posisi arsitektur dalam menyikapi kebutuhan masyarakat kelurahan Wijaya Kusuma?

\section{Tujuan}

1. Memberikan program untuk memenuhi kebutuhan masyarakat sesuai dengan tipe dan perilaku.

2. Memberikan program dan fasilitas yang dapat meningkatkan produktivitas dan keseimbangan sosial.

3. Memberikan wadah bagi anak - anak dan remaja untuk mengembangkan diri.

4. Merencanakan dan merancang arsitektur yang sesuai kebutuhan masyarakat sekitar.

5. Menciptakan ruang publik yang semakin baik, sebagai upaya interaksi sosial. 


\section{KAJIAN LITERATUR}

\section{A Third Place}

Pertumbuhan kota semakin memicu keberagaman kegiatan. Salah satu kecenderungan kegiatan masyarakat kota adaah adanya kebutuhan bertukar pengalaman dan memperoleh tempat yang nyaman untuk bersosialisasi. Kegiatan tersebut tidak dilakukan di rumah ataupun kantor, melainkan pada suatu tempatyang disebut ruang ketiga atau Third Place (Oldenburg, 1989). Tempat ketiga adalah istilah yang digunakan dalam konsep community building untuk merujuk sebuah lingkungan sosial yang memiliki karakter fisik yang berbeda dengan lingkungan sosial biasa di rumah ataupun kantor. Ray Oldenburg memberikan sedikit gambaran mengenai fungsi third place dengan frase "ow they get you through the day" (Oldenburg, 1989). Third place muncul ketika ada first place dan second place dirakan tidak cukup lagi. Setelah berakhirnya perang dunia, beberapa kota di dunia melakukan perencanaan dengan sistem zoning. Akibatnya jarak anatara daerah pemukiman dengan daerah publik menjadi jauh, sehingga harus ditempuh dengan menggunakan kendaraan. Keadaan ini menimbulkan kejenuhan dan berkurangnya aktivitas sosial yang dilakukan diluar rumah. Ditambah dengan kondisi lingkungan perumahan dimana tetangga tidak slaing mengenal satu sama lain, maka kebutuhan untuk menjalin interaksi sosial juga semakin tidak terpenuhi. Hal ini mengakibatkan tingginya tingkat stress pada masyarakat akibat kejenuhan.

Dapat terlihat bagaimana pentingnya keberadaan tempat - tempat dimana sesama manusia dapat menjalin informal "social interaction" dan melepaskan diri sejenak dari rutinitas kantor ataupun rumah (Oldenburg, 1989). Dalam bukunya, "The Great Good Place" Ray Oldenburg menggambarkan "A generic designation for a great variety of public places that host the reguler, voluntary, informal and happily anticipated gathering of individuals beyond the realsm of home or work". Menurut Oldenburg ada tiga setting kehidupan yang harus ada untuk memenuhi kebutuhan manusia akan place, yaitu home sebagai first place, tempat kerja sebagai second place dan tempat dimana orang dapat rutin berkunjung dan berkumpul dengan teman, tetangga sebagai third place.Terdapat beberapa karakter yang menjadikan Third Place berbeda dengan ruang publik. Third place digunakan sebagai ruang netral yang menyertakan semua pengguna ruang tersebut, biasanya digunakansebagai ruang informal dengan beberapa komunitas yang saling mengenal, melepaskan penat, mencari kesenangan, berada di tempat yang mudah dicapai dan memberikan kenyamanan bagi setiap orang yang dtaang (Oldenburg, 1989). Ray Oldenburg dalam buku "The Great Good Place" menjelaskan bahwa dalam tahapan perencanaan harus membuat keputusan yang tepat berdasarkan konsiderasi dan enak pemilihan elemen - elemen desain yang tepat, sehingga menghasilkan tempat yang layak dan memenuhi isu serta kebutuhan masyarakat.

Tabel 1. Perencanaan Pendekatan Elemen Desain dan Konsiderasi Terhadap Keputusan Desain

\begin{tabular}{|l|l|l|}
\hline Approach & Design Element & Consideration \\
\hline Place Making & Access and Linkage & $\begin{array}{l}\text { Movement pattern, insclusiveness, network } \\
\text { linkage, connectedness to surrounding and } \\
\text { visibility, entrance and exit }\end{array}$ \\
\hline & Comfort and Image & $\begin{array}{l}\text { Safety, maintanence, cleniness, public } \\
\text { furnitures \& facilities, convenience, } \\
\text { pedestrian scale }\end{array}$ \\
\hline & Uses and Activity & $\begin{array}{l}\text { Characteristics incorporated, activity, } \\
\text { function, regularity }\end{array}$ \\
\hline & Sociabillity & Sense of place, diversity, sociabillity, \\
\hline
\end{tabular}




\begin{tabular}{|l|l|l|}
\hline & & interactivity \\
\hline Lively Planning & Vibrant and Diverse & $\begin{array}{l}\text { Sociable stage, centralized amentities, } \\
\text { mixed use, attraction elements, activities }\end{array}$ \\
\hline & Temporary & $\begin{array}{l}\text { Enhancements, easy to changein order to } \\
\text { provide variety and ensure regularity }\end{array}$ \\
\hline & Creativity & $\begin{array}{l}\text { Linkage with surrounding and needs } \\
\text { withing specific location }\end{array}$ \\
\hline & Pedestrian Friendly & $\begin{array}{l}\text { Creative design, survave variety, tecture, } \\
\text { colour, shapes, city out }\end{array}$ \\
\hline Car free sone, walkability, bycicle friendly \\
\hline Green Urbanism & Multi-Sustainable & $\begin{array}{l}\text { Autenticity, consistency, } \\
\text { sustainability }\end{array}$ \\
\hline & $\begin{array}{l}\text { Green approach sustaining the aconomics, } \\
\text { enviromental and social perspective of } \\
\text { sustainable development }\end{array}$ \\
\hline & Multi-Scale & $\begin{array}{l}\text { Integration between land-use patterns, } \\
\text { benefit for the urban, neighbourhood and } \\
\text { human scale }\end{array}$ \\
\hline & Mesthetic Value & $\begin{array}{l}\text { Combined services benefit people to the } \\
\text { environtment and improve human - } \\
\text { nature interactions }\end{array}$ \\
\hline $\begin{array}{l}\text { Visually benefical, green-grey scale } \\
\text { improvement }\end{array}$ \\
\hline
\end{tabular}

Sumber : Olahan penulis, 2020

Third place merupakan bagian dari masyarakat yang dibutuhkan untuk membuat masysrakat lebih berinteraksi dan dapat meningkatkan inisiatif mereka terhadap sesama. Aksesibilitas pada tempat ketiga ini merupakan slaah satu hal yang penting dalam tahap perancangan (Oldenburg, 1989). Tempat ketiga yang menjadi tempat orang berkumpul sehingga "memiliki" status sosial yang sama dikarenakan oleh kegiatan yang dilakukan pada tempat ketiga ini. Arsitektur dalam pembentukannya mempunyai simbol tersendiri, sehingga menimbulkan intreperasi tertentu bagi masyarakat yang menimbulkan segregasi dan keengganan untuk datang ke bangunan tertentu. Dikarenakanoleh kesederhanaan yang dihasilkan oleh tempat tersebut, maka terlahirlah perasaan yang membuat tempat ketiga ini menjadi terbuka bagi siapapun yang akan mengunjunginya. Perlu diingat sebelum berlakunya persamaan hak manusia, pria harus bekerja diluar rumah dan wanita mengerjakan pekerjaan rumah dan mengurus anak di rumah. Maka itu, third place haruslah bersifat mono-gender yang tidak hanya memandang kepada dua jenis yang berbeda melainkan menyetarakan kegiataan dari kedua gender tersebu yang berdampak pada faktor psikologis individu. Tempat yang dirancang haruslah bersifat inklusif dan netral.

Tabel 2. Perbandingan penggunaan ruang

\begin{tabular}{|c|c|}
\hline Resticted & Shared \\
\hline Rules & Norm \\
\hline Hierarchy & Common \\
\hline Control & Freedom \\
\hline Stable & Critical \\
\hline
\end{tabular}

Sumber : Olahan penulis, 2020

Tempat ketiga pada saat ini merupakan sebuah tempat yang sangat mengakomodir berbagai macam komunitas tanpa melihat perbedaan dan latar belakang. Third Place bukanlah sebuah supermarket ataupunmall yang bersifat melayani dan menyediakan banyak hal di dalam tempat tersebut. Namun, tempat ketiga haruslah melayani dan dilayani dan memberikan 
layanan kepada tempat lain sehingga kedua tempat tersebut dapat saling membantu dan berkontribusi untuk masyarakat dari segi finansial dan pelayanan (Oldenburg, 1989).

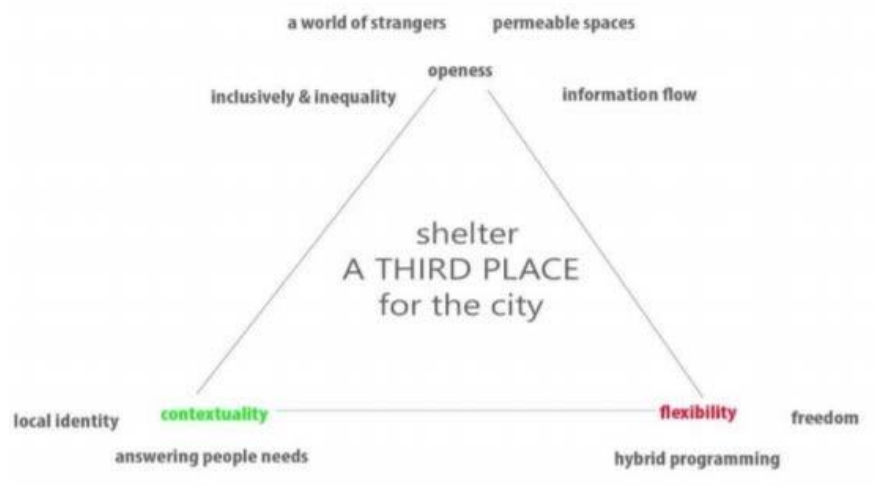

Gambar 1: Hubungan antara fungsi dan kebutuhan untuk merancang "Third Place" Sumber : Olahan Penulis

\section{Smart Cities - a Spatilized Intelligence}

Smart Cities menggunakan teknologi informasi dan komunikasi dalam upaya pembangunan ekonomi berkelanjutan dan mendorong bentuk - bentuk baru kehidupan kolektif. Ini menjadikan smart city fokus penting bagi para insinyur, arsitek, perancang dan perencana kota dan politisi, mengaitkannya dengan masalah budaya dan mengambil sikap yang benar - benar kritis dengan mencoba menguraikan konsekuensi pada ruang dan pengalaman perkotaan. Lensa budaya dan kritis ini jauh lebih penting karena smart city adalah cita - cita yang meresap oleh keyakinan utopis sebagai proses kongkrit transformasi perkotaan. Cita - cita ini memiliki karakter mandiri yang kuat: "kota - kota kita akan menjadi "cerdas" karena kami menginginkannya". (Picon, 2015)

Menurut Antonie Picon dalam buku ini, terdapat wacana dimana saat dibangunnya kota terdapat perancangan yang diterapkan dari chip dan sensor yang memungkinkan untuk memantau apa yang terjadi dalam infrastruktur hingga smartphone yang menghubungkan individu. Melalui teknologi ini ruang kota muncul sebagai diaktifkan hampir hidup. Aktivasi ini menghasilkan dua sisi yang berbeda : disatu sisi, ambisi neocybernetic untuk mengarahkan kota dengan cara yang paling efisien, dan disisi lain, pendekakatan partisipatif yang lebih bottom-up, dimana individu yang berdaya menemukan cara kerjasama baru. Analisis menyeluruh dari kedua trend ini mengungkapkan bahwa keduanya saling melengkapi. Kota cerdas dalam waktu dekat akan dihasilkan dari penyesuaian bersama. Dalam proses ini, ruang kota memainkan peran yang menentukan. Kota cerdas kontemporer dengan "pergantian spasial" digital.

Berdasarkan perkembangan teknologi utama seperti geolokalisasi dan augmented reality, meningkatnya pentingnya ruang menjelaskan peran strategis sembilan pemetaan dalam evolusi pengalaman perkotaan. Sepanjang penjelajahan beberapa faktor perancangan utama, bku ini terus - menerus bergerak dari teknologi ke tata ruang dan juga dari penilaian kritis atas eksperimen yang ada hingga spekulasi tentang muncunya bentuk baru kecerdasar kolektif. Di masa depan, kota - kota akan menjadi lebih pintar dengan cara lain yang jauh lebih literal daripada apa yang sering diasumsikan saat ini.

\section{Ruang Terbuka Hijau (RTH)}

Ruang terbuka (Open Space) merupakan ruang yang di rencanakan karena kebutuhan akan tempat- tempat pertemuan dan aktivitas bersama di udara terbuka. Ruang Terbuka (Open 
Space), Ruang Terbuka Hijau (RTH), Ruang Publik (Public Space) 13 mempunyai pengertian yang hamper sama . secara teoristis yang di maksud dengan ruang terbuka (Open Space) adalah:

a. Ruang yang berfungsi sebagai wadah untuk kehidupan manusia, baik secara individu ataupun kelompok, serta wadah mahluk lainnya untuk hudip dan berkembang secara berkelanjutan (UUPR no.24/1992)

b. Suatu wadah yang menampung aktivitas manusia dalam suatu lingkungan yang tidak mempunyai penutup berbentuk fisik ( Budihardjo,1999;90)

c. Ruang yang berfungsi antara lain sebagai tempat bermain aktif untuk anak-anak dan dewasa, tempat bersantai pasif untuk orang dewasa, dan sebagai area konservasi lingkungan hijau (Gallioen,1997;282)

d. Lahan yang belum di bangun atau sebagian besar belum di bangun di wilayah perkotaan yang mempunyai nilai untuk keperluan taman dan rekreasi; konservasi lahan dan sumber daya alam lainnya; atau keperluan sejarah dan keindahan (Gren,1962).

\section{Fungsi Ruang Terbuka Hijau (RTH)}

Dalam Peraturan Mentri Pekerjaan Umum No.05 Tahun 2008 tentang pedoman penyediaan dan pemanfaatan Ruang Terbuka Hijau di Kawasan Perkotaan. RTH memiliki fungsi sebagai berikut : Fungsi Utama (Intrinsik) yaitu fungsi ekologis :
a. Memberi jaminan pendanaan RTH menjadi bagian sdari system sirkulasi udara ( Paru-paru Kota)
b. Pengatur iklim mikro agar system sirkulasi udara dan air secara alami dapat berlangsung lancer
c. Sebagai peneduh
d. Produsen Oksigen
e. Penyerap air hujan
f. Penyerap polutan media udara,air dan tanah
g. Penahan angin

Fungsi tambahan (Eksentrik) yaitu :

a. Fungsi Sosial dan Budaya, yaitu menggambarkan budaya lokal; merupakan media komunikasi bagi warga kota ; tempat rekreasi; wadah dan objek pendidikan, penelitian dan pendidikandan pelatihan mempelajari alam.

b. Fungsi Ekonomi, yaitu menjual produk seperti tanaman bunga,sayur buah daun ; bias juga menjadi usaha pertanian, perkebunan dan kehutanan.

c. Fungsi Estetika Dalam suatu wilayah 3 fungsi utama ini dapat di kombinasikan sesuai kebutuhan, kepentingan dan keberlanjutan kotaseperti perlindungan tata air, keseimbangan ekologi dan konservasi hayati.

\section{Behavorial Architecture}

Hal yang harus diperhatikan dalam merancang bangunan terutama dalam Behavioral Architecture supaya peran bangunan dapat berfungsi sebagai suatu pelayanan sosial maka elemen - elemen yang harus dipertimbangkan yaitu (Heimsath,1998):

a. Kegiatan sosial yang ditampung dalam bangunan

b. Fleksibilitas yang dibutuhkan pada tiap kegiatan

c. "Kegiatan - kegiatan" yang mempengaruhi atau dipengaruhi

d. Latar belakang dan sasaran pengguna ruangan

Dari elemen - elemen diatas, bisa didefinisikan Behavioral Architecture adalah ilmu merancang yang mengacu pada aspek - aspek yang mendasar dan terkait dengan sikap dan tanggapan manusia terhadap lingkungannya, bertujuan untuk menciptakan ruang dan suasana tertentu yang sesuai dengan perilaku manusia beserta lingkungan dan budaya masyarakat. Adanya 
prinsip - pronsip yang harus dipertimbangkan dalam arsitektur perilaku antara lain (Tandal dan Egam,2011):

a. Mampu berkomunikasi dengan manusia dan lingkungannya

Dari bangunan yang diamati oleh manusia syarat - syarat yang harus dipenuhi adalah :

- Pencerminan fungsi bangunan

- Menunjukkan skala dan proporsi yang tepat serta dapat dinikmati

- Menunjukkan bahan dan struktur yang aka digunakan dalam bangunan

b. Mewadahi aktivitas penghuninya dengan nyaman dan menyenangkan

- Nyaman secara fisik dan psikis. Nyaman fisik berarti kenyamanan thermal, nyaman psikis akan tercipta rasa senang dan tenang

- Menyenangkan dapat dijabarkan dalam beberapa aspek menyenangkan secara fisik, dapat timbul dengan adanya pengolahan pada bentuk dan ruang yang ada disekitar; menyenangkan secara psikologis, dapat timbul dengan adanya pemenuhan kebutuhan berkaitan dengan jiwa manusia, menyenangkan secara kultural, dapat timbul dengan adanya penciptaan karya arsitektur yang sudah dikenal masyarakat yang berada di tempat tersebut

c. memenuhi nilai estetika, komposisi, dan estetika bentuk

\section{Kajian Tipologi Dalam Perancangan Arsitektur}

Definisi Tipologi Dalam Arsitektur

Tipologi adalah sebuah diskursus ilmu yang berhubungan dengan tipe dimana, Tipologi berasal dari kata 'tope' dan -'ologi' berasal dari Bahasa Yunani 'logika' yang berarti diskursus, teori, atau ilmu yang mendukung.

\section{Pengenalan Tipologi Fungsi Bangunan}

Tipologi bangunan merupakan bentuk golongan yang dikenal dalam Arsitektur. Di Indonesia dikenal 11 tipologi fungsi bangunan yang sesuai dengan "Time Save Standarts For Builiding Types".

\begin{tabular}{|ll|l|}
\hline \multicolumn{3}{|c|}{ PENGELOMPOKAN UTAMA TIPOLOGI FUNGSI BANGUNAN } \\
\hline 1. & Residential & = sarana perumahan \& pemukiman \\
2. & Educational & = sarana pendidikan \\
3. & Cultural & = sarana kesenian dan kebudayaan \\
4. & Health & s sarana kesehatan dan kesejahteraan \\
5. & Religious & $=$ sarana keagamaan dan peribadatan \\
6. & Govermental \& public buildings & $=$ sarana pemerintahan \\
7. & Commercial & = sarana bisnis dan komersial \\
8. & Transportations & $=$ sarana transportasi \\
9. & Industrial & = sarana industri \\
10. & Recreation \& entertainment & $=$ sarana hiburan dan rekreasi \\
11. & misscellaneous & $=$ sarana olahraga dan kebugaran \\
\hline
\end{tabular}

Gambar 2. Pengelompokan Tipologi Fungsi Bangunan

Sumber : Joseph De Chiara, 1973

\section{METODE}

\section{Metode Pengumpulan Data}

Sebelum masuk ke dalam perancangan, penulis melakukan penelitian untuk pengumpulan data sebagai dasar perancangan, berikut merupakan tahapan proses penelitian :

a. Pengumpulan Studi Literatur

Pengumpulan studi literatur yang dilakukan penulis adalah mencari data tentang lokasi yang akan diteliti diantaranya yaitu, peta global, peta zonasi, peta nilai tanah, dan beberapa artikel tentang lokasi.

b. Survey Lapangan 
Survey lapangan dilakukan untuk mengetahui berbagai kejadian yang terjadi. Penulis berfokus pada pengamatan perilaku masyarakat sekitar, pengamatan titik - titik kegiatan masyarakat, mencari peluang untuk keberhasilan proyek, dan pengamatan mengenai stenght, weakness, oppurtunities, threats (SWOT). Selain itu penulis juga melakukan wawancara dengan beberapa masyarakat sekitar.

\section{Metode Perancangan Desain}

Cross - Programming menggunakan ruang spasial yang tidak sesuai dengan program asalnya. Misalnya bangunan ibadah digunakan sebagai klub malam, menempatkan suatu konfigurasi pada lokasi yang tidak 15 berkaitan, atau menempatkan museum 16 di bangunan parkir. (Mantiri dan Makainas, 2011). Konsep cross-programming ini meliputi dua aspek yaitu:

a. Aktivitas harus bisa tumpang tindih.

b. Bangunan harus mampu beradaptasi dengan program yang berbeda dari waktu ke waktu.

Kedua konsep tersebut memungkinkan untuk pengarahan dialog dengan menekankan transformasi, adaptasi, dan perubahan sebagai alur desain. Sesuai konsep ini bangunan harus dirancang untuk beberapa fungsi sehingga bangunan memiliki umur lebih lama dan lebih berkelanjutan. Konsep ini juga akan meningkatkan hubungan antara pengguna dengan lingkungan sekitar bangunan (Novielle, 2007). Dalam Proyek Dalam perancangan proyek ini penulis menggunakan metode Cross-Programming dengan menggunakan ruang spasial yang tidak sesuai dengan fungsi asalnya. Dengan mencakup dua aspek yaitu :

a. Aktivitas harus bisa tumpang tindih.

b. Bangunan harus mampu beradaptasi dengan program yang berbeda dari waktu ke waktu.

Dalam proyek ini akan ditunjukan pada ruang / lapangan olahraga yang akan sewaktu - waktu dapat berubah fungsi dengan kegiatan yang lainnya seperti pentas seni ataupun budaya yang ada di masyarakat sekitar .

\section{DISKUSI DAN HASIL ANALISIS LOKASI Pertimbangan Pemilihan Lokasi}

Ada beberapa pertimbangan yang harus diperhatikan melalui beberapa kriteria menurut penulis. Berikut ini merupakan kriteria pemilihan lokasi yang sesuai dengan proyek :

a. Lokasi terletak di tengah kota dengan ruang antara fungsi campuran dan hunian

b. Merupakan lokasi aktif yang berada di tengah keramaian

c. Lokasi memiliki luas lahan yang cukup besar untuk mewadahi program

d. Lokasi strategis dan mudah diakses dengan konsep TOD atau dapat dijangkau dengan kendaraan umum

e. Lokasi dapat dijangkau bagi pejalan kaki dengan radius $\pm 500 \mathrm{~m}$

Berdasarkan kriteria di atas, tapak yang diambil berada di Jalan Karya Barat III, Kelurahan

Wijaya Kusuma, Kecamatan Grogol Petamburan, Jakarta Barat.

\section{Kelurahan Wijaya Kusuma, Kecamatan Grogol Petamburan, Jakarta Barat}

Wijaya Kusuma adalah kelurahan yang terletak di kecamatan Grogol Petamburan, Jakarta Barat, Daerah Khusus Ibukota Jakarta, Indonesia. Jumlah penduduk di kelurahan Wijaya Kusuma 
mencapai 38.102 jiwa dengan 18.337 penduduk laki - laki dan 19.765 penduduk perempuan dengan sex ratio 93. Kepadatan Wijaya Kusuma adalah yang ketiga setelah Tambora. Mayoritas penduduk kelurahan Wijaya Kusuma bekerja sebagai karyawan. Angkutan Wijaya Kusuma dilayani oleh layanan Bajaj, KRL yang terdapat di stasiun Pesing dan terdapat juga beberapa angkutan umum lainnya. Berikut merupakan beberapa sarana yang terdapat di kelurahan Wijaya Kusuma:

Tabel 3. Sarana Pendidikan di Kelurahan Wijaya Kusuma

\begin{tabular}{|c|c|c|c|c|}
\hline & TK & $\begin{array}{c}\text { S } \\
\text { D }\end{array}$ & SMP & SLTA \\
\hline $\begin{array}{c}\text { Kelurahan Wijaya } \\
\text { Kusuma }\end{array}$ & 1 & 12 & 11 & 12 \\
\hline
\end{tabular}

Sumber : Olahan penulis, 2020

Tabel 4. Sarana Kesehatan di Kelurahan Wijaya Kusuma

\begin{tabular}{|c|c|c|c|c|c|}
\hline & $\begin{array}{c}\text { Rumah } \\
\text { Sakit }\end{array}$ & Puskesmas & Poliklinik & $\begin{array}{l}\text { Praktek } \\
\text { Dokter }\end{array}$ & Apotek \\
\hline $\begin{array}{c}\text { Kelurahan Wijaya } \\
\text { Kusuma }\end{array}$ & 1 & 2 & 4 & 12 & 6 \\
\hline
\end{tabular}

Sumber : Olahan penulis, 2020

Tabel 5. Sarana Olahraga di Kelurahan Wijaya Kusuma

\begin{tabular}{|c|c|c|c|c|}
\hline & Sepak Bola & Tenis & Badminton & Volley \\
\hline $\begin{array}{c}\text { Kelurahan Wijaya } \\
\text { Kusuma }\end{array}$ & 1 & 0 & 6 & 6 \\
\hline
\end{tabular}

Sumber : Olahan penulis, 2020

Selain itu juga terdapat sarana ibadah seperti, gereja, masjid, dan kuil yang tersebar di Wijaya Kusuma. Wijaya Kusuma juga dikenal dengan berbagai kedai makanannya. Warung makanan Cina terkonsentrasi di daerah Dutamas. Adapun kekurangan yang dimiliki kelurahan Wijaya Kusuma diantaranya adalah kurangnya sarana bermain anak - anak dan remaja, kondisi lingkungan yang sangat padat sehingga dapat berpengaruh pada perkembangan anak - anak .

\section{Data Tapak Terpilih}

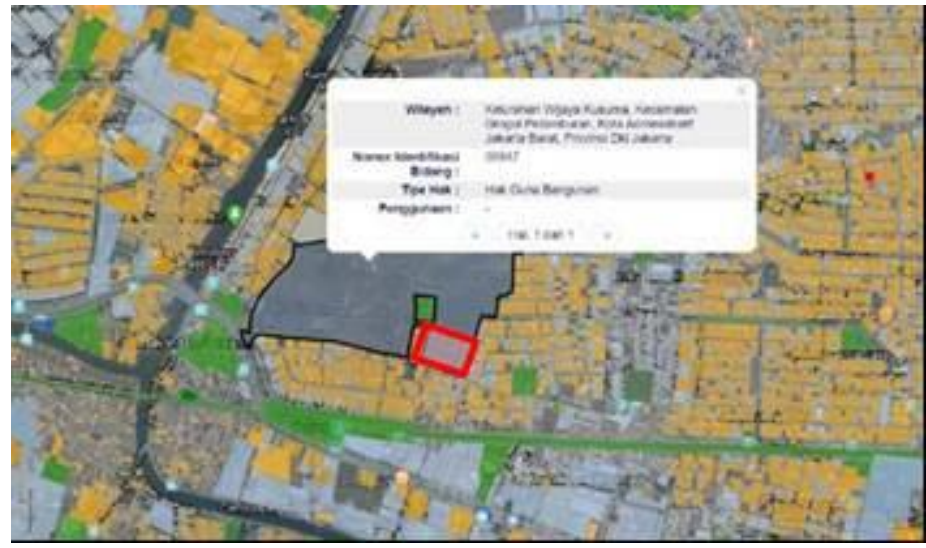

Gambar 3. Peta Nilai Tanah Tapak terpilih

Sumber : https://www.atrbpn.go.id/Peta-Bidang-Tanah\# , 2020 


$\begin{array}{ll}\text { Luas Tapak } & = \pm 5.000 \mathrm{~m}^{2} \\ \mathrm{~KB} & =4 \\ \mathrm{KDB} & =30= \pm \\ 1.500 \mathrm{~m}^{2} & \end{array}$

$\mathrm{KDH}=30= \pm 15.00 \mathrm{~m}^{2} \mathrm{KLB}=1,2= \pm 6.000$

$\mathrm{m}^{2} \mathrm{KTB}=55= \pm 2.750 \mathrm{~m}^{2}$

Lokasi tapak yang terpilih merupakan area yang dominan dengan sraana pendidikan dan permukiman, menurut peraturan zonasi, lokasi tersebut memiliki fungsi S.5 yang berarti sub zona prasarana olahraga dan rekreasi. Pada bagian timur merupakan area perkantoran, pada bagian barat dan selatan merupakan area permukiman dan pada bagian utara merupakan area pendidikan dan permukiman. Kondisi pada lokasi yang terpilih cukup padat dan juga aktif pada pagi hingga sore hari menurut hasil survey, karena sebagian besar pengunjung yang datang merupakan siswa/i dan karyawan kantor yang bekerja.

\section{PROSES PROGRAM}

Analisa Program Kegiatan

Sebagai third place proyek Pusat Komunitas Olahraga Dan Seni ini memiliki 3 aspek yang berdasarkan kebutuhan masyarakat sekitar diantaranya :

a. Aspek Sosial-flexible program

Merupakan kebutuhan interaksi bagi masyarakat sekitar yang bertujuan untuk menciptakan kedekatan.

- Ruang Serbaguna

Merupakan pusat aktivitas kumpul masyarakat Kelurahan Wijaya Kusuma dan juga komunitas olahraga dan seni yang ada. Kegiatan yang dilakukan dapat berupa penyuluhan warga, tempat untuk hajatan atai intuk perayaan hari besar.

b. Aspek Edukasi-fixed program

Merupakan kebutuhan dari program utama proyek ini yaitu kegiatan olahraga dan seni, yang mana ruang kegiatan olahraga dan seni ini bersifat multifungsi satu sama lain antara kegiatannya.

- Pelatihan futsal / basket

- Pelatihan badminton / tenis meja

- Pelatihan pencak silat / atletik

- Pelatihan renang

- Pelatihan seni tari

- Pelatihan seni musik

- Pelatihan seni lukis / gambar

c. Aspek Rekreasi - flexible program

Merupakan kebutuhan masyarakat sekitar yang sesuai dengan karakteristiknya dan juga masyarakat luas.

- Lapangan terbuka

Sebagai sarana olahraga bagi masyarakat sekitar yang dapat dialihfungsikan sebagai sarana rekreasi ataupun kegiatan masyarakat lainnya seperti, acara 17 agustusan, acara dangdutan, dll.

- Sitting group

Sebagai sarana bagi masyarakat untuk dapat berdiskusi dan menikmati suasana di sekitaran proyek dengan masyarakat lainnya ataupun dengan komunitas.

- Playground

Sebagai sarana bermain bagi anak - anak disekitaran proyek. Tujuan dibuatnya playground ini adalah agar anak - anak juga dapat berpartisipasi dalam proyek ini sebagai pengguna, karena proyek ini dibuat untuk segala kalangan umur dari anak anak hingga orang tua. 


\section{PROSES DESAIN}

\section{Strategi Desain}

Pusat komunitas olahraga dan seni dirancang dengan beberapa strategi desain yang memperhatikan tipe dan perilaku masyarakat sekitar yang merupakan pengguna proyek ini sebagai sasaran utama. Strategi desain dalam area sirkulasi dan berkumpul juga menggunakan metode tipologi yang berdasarkan preseden bangunan komunitas anak muda yang suda ada dibeberapa negara dan menganalisis bagaimana program yang dibuat dimasukkan ke dalam bangunan. Dalam desain pengolahan massa juga dilakukan dengan studi tipologi dari arsitektur grid sehingga bangunan pusat komunitas olahraga dan seni dapat mempresentasikan ruang dengan baik.

\section{Konsep Massa}

Berdasakan analisis yang dilakukan terhadap tipologi dan bentuk bangunan yang mengutamakan lingkungan sekitar dan tipologi grid. Pusat komunitas olahraga dan seni ini memiliki dua massa utama yang berada di sisi timur dan barat. Kedua massa tersebut digabungkan dengan sebuah massa yang merupakan area komunal dan area service bangunan yang terkesan seperti jembatan sebagai konektivitas antar massa. Berikut merupakan gambar blok plan yang memperlihatkan terdapat dua massa yang digabungkan oleh sebuah jembatan atau konektor.

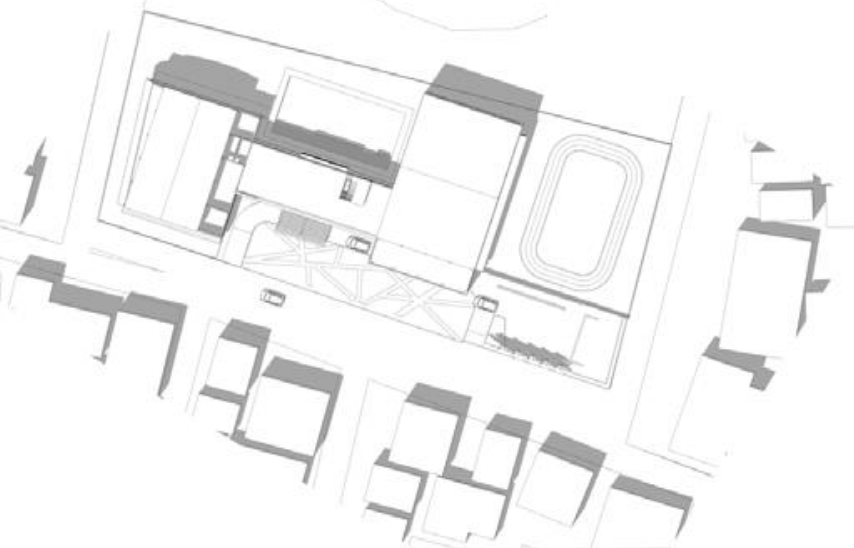

Gambar 4. Blok plan

Sumber : olahan penulis, 2020

\section{Konsep Ruang Luar}

Konsep ruang luar dibuat sangat terbuka sehingga pengunjung dapat merasakan elemen alam yang ada disekitar bangunan. Ruang luar bangunan ini terbentuk dari dua elemen yaitu permainan hardscape dan softscape. Pada bagian ruang luar juga dibuat beberapa program yang dapat dinikmati oleh pengguna seperti lapangan outdoor, kolam renang, dan taman.

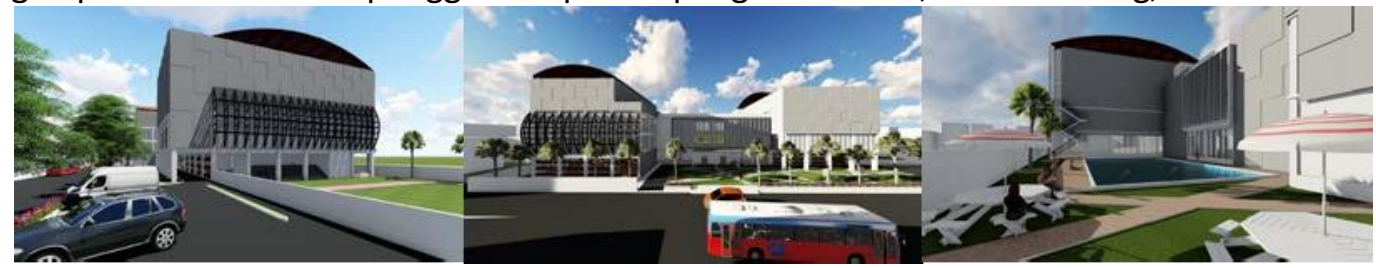

Gambar 5. Suasana ruang luar

Sumber : Olahan penulis, 2020 


\section{Konsep Ruang Dalam}

Pada bagian ruang dalam didesain terbuka dan menyatu dengan sekitar. Diberikan banyak bukaan pada area komunal untuk menekankan pengalaman ruang dimana mendapatkan kesan terbuka. Bagian kegiatan olahraga dan seni didesain bersifat tertutup untuk kenyamanan pengguna dan sesuai standart kebutuhan ruang kegiatan tersebut.

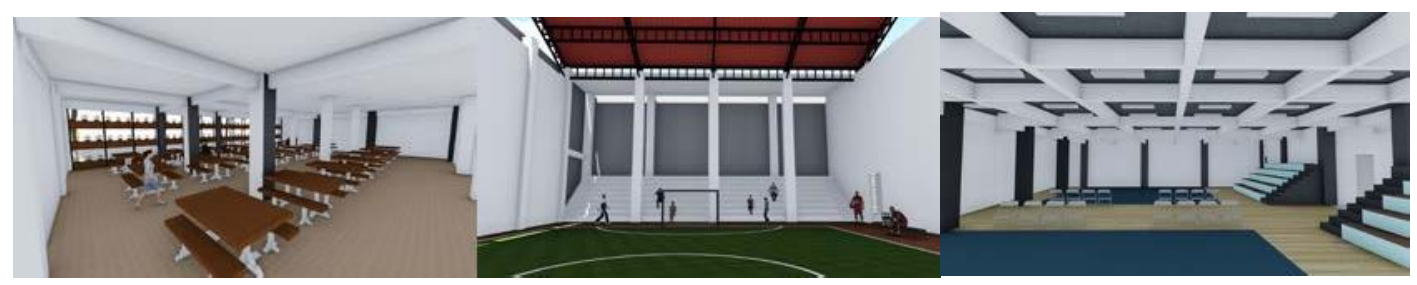

Gambar 6. Suasana ruang dalam

Sumber : Olahan penulis, 2020

\section{Pembentukan Massa}

Bentuk massa bangunan pada dasarnya terbagi menjadi 3 bagian. Pada sisi kanan dan kiri bangunan merupakan bagian yang di lantai teratasnya terdapat massa bentang lebar yang berfungsi sebagai lapangan untuk kegiatan olahraga dan pada bagian bawahnya merupakan fungsi - fungsi lain seperti ruang kegiatan seni dan juga area kantor pengelola. Pada bagian tengah bangunan merupakan ruang komunal yang berfungsi sebagai penghubung kedua kegiatan olahra dan juga seni. Selain itu pada bagian tengah juga merupakan area service dan juga sirkulasi vertikal bangunan.

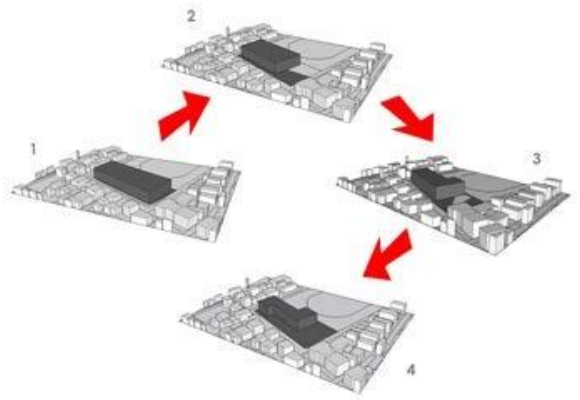

Gambar 7. Proses gubahan massa Sumber : Olahan penulis, 2020

\section{PROGRAM}

Program dipisahkan berdasarkan area pengelompokan kegiatan yang berpusat pada area komunal / area publik yang terdapat di bagian tengah bangunan. Seperti yang tergambarkan pada gambar dibawah.

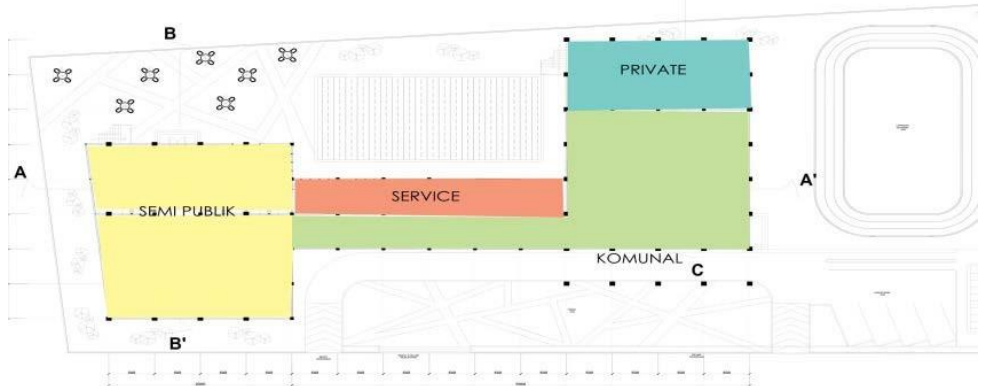

Gambar 8. Pembagian ruang lantai 1 Sumber : olahan penulis, 2020 
Berikut merupakan penjabaran pembagian kelompok ruang berdasarkan sifatnya :

a. Private

Merupakan area yang bersifat tertutup seperti kantor.

b. Semi Publik

Merupakan area yang bersifat terbuka akan tetapi terdapat batasan seperti ruang - ruang kegiatan olahraga dan seni yang ada didalam proyek ini.

c. Publik / Komunal

Merupakan area yang bersifat terbuka dan siapapun dapat melakukan kegiatan ataupun aktivitasnya diruangan tersebut yang diantaranya adalah ruang serbaguna, kantin, sitting group, playground, lapangan terbuka, dll.

d. Service

Merupakan area yang bersifat tertutup dan melakukan kegiatan maintenance bangunan seperti, toilet, ruang panel, AHU, ruang pompa, GWT, FWT, STP, dll.

Program utama yang terdapat pada proyek ini terbagi menjadi 3 program utama yaitu :

a. Kegiatan Olahraga - sport area

b. Kegiatan Seni - art area

c. Ruang komunal-communal space

Didalam program tersebut terdapat berbagai macam kegiatan yang dapat dilakukan . Ruang komunal merupakan ruang antara dari kegiatan olahraga dan kegiatan seni yang ada dalam proyek ini. Ruang komunal dapat juga disebut sebagai ruang penghubung diantara kegiatan olahraga dan kegiatan seni. Berikut merupakan gambar penjabaran program proyek.

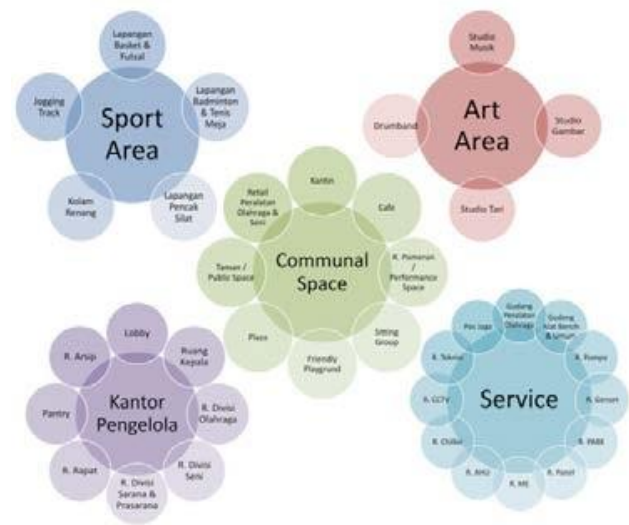

Gambar 9. Program pengelompokan Kegiatan Sumber : Olahan penulis, 2020

\section{Social Space}

Tujuan utama dari proyek ini adalah menciptakan ruang publik yang baik bagi masyarakat sekitar sehingga dalam proyek ini memberikan kesan yang sangat terbuka bagi masyarakat untuk dapat menggunakan fasilitas yang ada didalam proyek ini. Dapat digambarkan pada penciptaan ruang yang terbuka. Terdapat lapangan terbuka yang cukup luas bagi masyarakat untuk melakukan kegiatan sosial, tempat berdiskusi atau tempat untuk sekedar duduk dan berbincang ataupun menikmati suasana disekitar. 


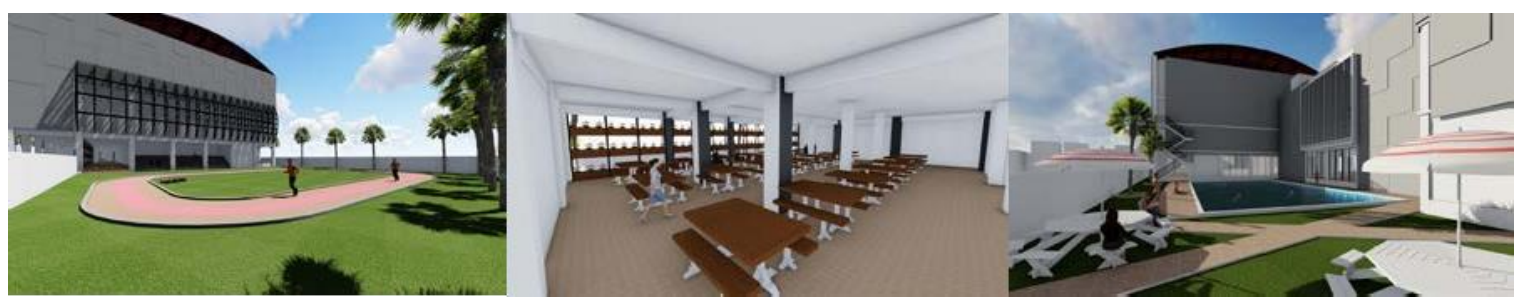

Gambar 10. Suasana ruang publik

Sumber : Olahan penulis, 2020

\section{KESIMPULAN DAN SARAN}

\section{Kesimpulan}

Proyek Ruang Ketiga "Pusat Komunitas Olahraga dan Seni" memberikan ruang bersama pubik yang terancang bagi masyarakat Kelurahan Wijaya Kusuma, Kecamatan Grogol Petamburan, Jakarta Barat. Dengan pendekatan cross-programming proyek ini dapat menggabungkan kegiatan bagi masyarakat sekitar dan juga komunitas yang ada. Pusat komunitas olahraga dan seni dirancang dengan beberapa strategi desain yang memperhatikan tipe dan perilaku masyarakat sekitar yang merupakan pengguna proyek ini sebagai sasaran utama. Selain itu juga program yang diterapkan dalam proyek ini dapat digunakan bagi masyarakat sekitar yang bersifat flexible untuk kegiatan kemasyarakatan seperti perkumpulan warga, acara 17 Agustus ataupun kegiatan hari raya besar lainnya dengan menggunakan ruang - ruang serbaguna yang ada di dalam proyek ini. Dengan adanya partisipasi dari komunitas proyek ini dapat memberikan edukasi bagi masyarakat sekitar mengenai olahraga dan juga seni.

\section{Saran}

Penulis menyarankan adanya penelitian lebih lanjut mengenai kegiatan masyarakat ataupun komunitas yang berhubungan dengan olahraga dan seni di berbagai daearah ataupun kota lainnya dan berharap jika ada pembangunan dari pemerintah ataupun non-pemerintah, dapat didasari dari pengumpulan data dari masyarakat atau komunitas di daerah tersebut, karena setiap masyarakat atau komunitas di suatu daerah memiliki karakter masing - masing.

\section{REFERENSI}

Anthony, A.C. (2003). Poetics Of Architecture. New York: Van Nostrand Reinhold.

Broadbent, G. (1980). Design in Architecture. California: Hilde Publishing.

Florida, R. (2012). The Rise of The Creative Class (Vol.34). California: Basic Books. doi: $368251 / f 85969$

Mah, K. (2013). Architecture \& The Human Behaviour, diakses 15 Februari 2020, di https://www.academia.edu/7383370/Architecture_and_the_Human_Behaviour.

Oldenburg, R. (1989). The Great Good Place. NewYork: Da Capo Press.

Picon, A. (2015). Smart Cities: A Spatialized Intelligence. Michigan: Wiley Ann Harbor. 